\title{
Winds of change stirring for West German telecommunications
}

\section{Munich}

POWERFUL forces are moving into position in anticipation of a battle this autumn to deregulate portions of West Germany's telecommunications industry. Although the Deutsche Bundespost - the government agency in charge of post and telephone services - has so far successfully resisted efforts to break its monopoly over these services, an official commission has recommended that a "new age" for telecommunications be ushered in by the end of next year.

There has long been pressure on the Deutsche Bundespost to open up its markets to West German and international competition. But the Ministry for Posts and Telecommunications, which runs the Bundespost, has always had the power to resist. This is in part because of its tremendous size - with an annual investment of DM 17,000 million, it is West Germany's largest investor - and in part because it provides almost DM5,000 million in revenue every year.

But a commission, made up of representatives from industry, trades unions, government and political parties, calls for a separation of telephone and datatransmission from postal services and a new tariff structure allowing long-distance telephone rates to fall and local rates to rise on the basis of the cost of providing these services. Local telephone services, as well as long-distance networks, would remain under the administration of the 'postal monopoly' whereas most other services, such as telefax or teletext, would be opened up to West German and foreign suppliers over the next five years. Although hardly revolutionary in their scope, the commission's recommendations were met with withering criticism from the Social Democratic Party (SPD), the postal union and segments of the electronics industry.

The coupling of local with long-distance telephone services, and of postal delivery with telecommunications, has allowed the Bundespost to generate huge profits while still providing social services such as cheap package delivery and low local telephone rates. According to a survey by the Austrian magazine Profil, West Germany has only the sixth-highest local rates among Western European countries, but by far the highest costs for longdistance calls over $100 \mathrm{~km}$, with rates three times as high as Britain or Belgium.

Supporters of the postal monopoly argue that the controlled prices are necessary for the Bundespost to provide the social services, such as cheap newspaper delivery, that are now expected of it. Furthermore, they say, the average citizen profits from low local rates whereas big companies foot the bill for long-distance communication. A bizarre alliance of the left-of-centre SPD, some trades unions and the far-right Christian Social Union has publicly denounced the proposed deregulation because it opens up the market to companies that would "pick the raisins out" of the telecommunications industry - namely lucrative high-speed data and voice transmission between large cities - leaving the average citizen to pay the cost through higher rates or poorer service.

On the other side of the debate, the Economics Ministry and the Free Democratic Party argue that the current system is rife with inefficiency. They go so far as to favour the creation of competing satellite or cable networks as a way of forcing down long-distance prices.

Three of the most influential science and education organizations in West
Germany, the Wissenschaftsrat, Westdeutsche Rektorenkonferenz and Deutsche Forschungsgemeinschaft (DFG), have added their voices to the current cacophony by calling for reduced rates for scientific use of telephone and data lines.

Wissenschaftsrat (science council) official Kurt-Jürgen Maass would prefer to see the telephone system administered like a private business, as the commission proposed, in the hope that scientists and students would receive the same discounts as they do when they buy computer hardware - up to 40 per cent in some cases.

The battle over deregulation will hot up after 16 September, when the commission report is officially submitted to Chancellor Helmut Kohl. A parliamentary resolution is expected to follow. The commission's target date for implementing changes in the Bundespost - $1 \mathrm{Jan}$ uary 1989 - seems decidedly over-optimistic in the light of the political infighting that is bound to break out with the return of the Bundestag to Bonn after the summer recess is over.

Steven Dickman

\section{Czech uranium miners up in arms over working conditions}

\section{London}

URANIUM miners at the Zadni Chodov complex in West Bohemia (Czechoslovakia) have signed a "comprehensive complaint" against working conditions and the suppression of information about health hazards, according to the Czechoslovak party newspaper Rude Pravo. The "complaint" was signed several months ago; three reporters from Rude Pravo met with the principal petitioners in May. The delay in publication suggests high-level consultations before the article could appear.

The miners said that they had never been officially informed about the regulations on radiation hygiene, and only found out about them "by chance". One who complained about the high level of radioactivity to which miners were exposed was informed by the chief engineer that he was "talking too much". Miners who had to be transferred from underground work on health grounds suffered losses in pay and were not informed of the social security benefits to which they were entitled. Moreover, although their impaired health was due to past breaches of the safety regulations, and what they considered to be the management's "irresponsible gambling" with their health, they had difficulty in obtaining the documents necessary to file a claim for damages.

Doctors, the miners claimed, were "under the influence" of the management. Records of dosimetric measurements were forged, and miners who asked for sickleave after minor accidents were pressurized not to do so, because this would allegedly deprive the managers of their bonuses. One one occasion, the miners claimed, a ventilation system had been taken out of operation to save energy, although the mine was fully manned.

Representatives of the management, foremen and "other miners" interviewed by Rude Pravo denied these allegations, although the director of the enterprise did admit to a certain "disorder" in recordkeeping. Management, he promised, would "deepen the methodological supervision of the entire mine" and had already instituted "consultation days", when workers could talk to specialists on matters of safety, wages and legal rights.

The protesting miners, however, say that they have lost all trust in the management and are "no longer interested" in talking to it. The Rude Pravo team noted that there was "no proof" of falsification and misreporting alleged by the protesters - but stressed that the incident revealed an "under-estimation of daily genuine contact with the people" on the part of the party and trades union organizations. Unresolved conflicts and lack of "openness", they concluded, create scope for misunderstandings, slanders, suspicion and accusations, to say nothing of a considerable expenditure of time, money and human effort in resolving such conflicts.

Vera Rich 